\title{
Strengthening of the Coal-Gasification Industry: Evidence from Indonesia
}

\author{
Ragimun Abdullah ${ }^{1 *}$, Haula Rosdiana ${ }^{2}$ \& Milla Sepliana Setyowati ${ }^{3}$ \\ ${ }^{1}$ Fiscal Policy Agency, Ministry of Finance, Jakarta, Indonesia \\ 2,3Faculty of Administrative Science, University of Indonesia, Depok, Indonesia \\ ragimun@gmail.com, haula.rosdiana2013@gmail.com,milla_ss@ui.ac.id
}

\begin{abstract}
The purpose of this research is to analyze Indonesia's coal-gasification industry policy. This research needs to map the undeveloped coal-gasification industry. In fact, the coal-gasification industry can increase the economic value of coal, increase local income, absorb the labor force, and reduce pollution. It also has some strategic roles in national fiscal revenue and foreign exchange reserves and is of great significance to regional development. The research methods used are quantitative and qualitative. The results of this study indicate that government needs to provide some financial incentives for the coal-gasification industries, especially for pioneer companies for having coal-gasification works, and ensure that policies taken will be able to encourage economic growth and investment in Indonesia's coal-gasification industry. To support investment in the coal-gasification industry, it is necessary to formulate policies and rules to provide a sign for its implementation.
\end{abstract}

Keywords: Coal, gasification industry, fiscal incentives policy.

\section{Introduction}

Indonesia is a country with abundant natural resources such as oil, natural gas, minerals and coal (Anjar, et al., 2019; Marques, et al., 2019). In order for these natural resources to provide the greatest possible prosperity to the community, their management must be carried out wisely and always consider various aspects. These aspects include economic, social and environmental aspects (Alin, 2004; Sutthichaimethee, 2018). One of the abundant natural resources that have not been managed optimally is coal. The spread of potential coal reserves in Indonesia can be found in several areas, including Kalimantan, Sumatra, Papua and several other regions. The potential content of coal resources in Indonesia is estimated at 151 billion tonnes with coal reserves of 39 billion tonnes. However, if there are no innovation efforts in coal processing, coal reserves are expected to be depleted in the next 70 years, so that by 2090 Indonesia's coal reserves will run out (Geological Agency, 2018). According to Deon Arinaldo, et al. (2019), there is a transition period for the management and utilization of coal in Indonesia. The management and utilization of coal require medium and long-term planning related to collaborative cooperation between various sectors, agencies, ministries and local governments to optimize the benefits of coal. This is because coal still has an important role in Indonesia's trade balance and economic development in several regions. Another reason is increasing economic value through the mining process and in the development of the downstream coal industry. This is believed to be one of the alternatives to increase the multiplier effect for the national economy (Wang, 2017).

On the other hand, it will be able to reduce dependence on exports of raw material commodities that have not been further processed. Currently, cooperation among some ministries, such as the Ministry of Industry, the Ministry of Energy and Mineral Resources, the Ministry of Industry, the Ministry of Finance and the Ministry of Home Affairs is needed to build certain a policy framework to optimize coal's economic value trough coal gasification works. Coal mining has a huge contribution to state incomes, either from charges and noncharges, like fixed expenses, abuse expenses or eminences. Realization of Coal Non-Charges State Revenues continues to increase. In 2018 and 2019 it reached USD 1,492,216,540 and USD 1,375,840,980 (Ministry of Finance of Indonesia, 2020). Indonesia's coal holds are as of now recorded at 3 percent of the world's absolute coal saves. While the structure comprises of low-calorie coal content, adding up to 29 percent, medium calories by 64 percent, while the high and very high-calorie composition is 4 and 3 percent. For high and very high-calorie coal, mining entrepreneurs are usually exported directly because of the high price. For low and medium-calorie coal content, the Government continues to encourage added-value enhancement. One of them is through the gasification process. This process is to convert coal from solid form to Dimethyl Ether (DME) so that it can be consumed like Liquified Petroleum Gas (LPG) which is commonly consumed by households so far. The gasification industry is expected to support the coal downstream program in Indonesia, and the coal utilization program optimally. 
Likewise, it can reduce the amount of LPG imports so that there are savings in foreign exchange. On the other hand, subsidies have also decreased, the supply of LPG has increased and the price of LPG has become cheaper. Another benefit of the coal-gasification industry is the absorption of labor and an increase in regional revenue where the gasification industry is located. Currently, not many mining companies in Indonesia are interested in developing a coal-gasification program. The main obstacle is gasification technology and very high investment costs. Right now there is just one state-possessed organization that will turn into a pilot project for the improvement of the coal-gasification industry, namely PT Bukit Asam in collaboration with PT Pertamina, PT. Pupuk Indonesia and PT. Candra Asri. PT Bukit Asam is one of the pilot project objects. Currently, it continues to carry out business efficiency to start a gasification project that is feasible or economically feasible, as well as obtaining bank financing support. Gasification technology is currently very possible to be developed. Several countries have also succeeded in carrying out the coalgasification industry.

As an alternative energy, such as China, the United States, South Korea, Mongolia and Japan (Fei, 2016). The main problem of the coal-gasification industry for mining companies in Indonesia is the very high investment costs, so that this project may be given incentive support from the government to encourage the gasification industry to develop. Currently, the investment needed to start the coal gasification industry is the US \$ 2.4 billion (Kontan.co.id, 2020). One of the supports that can be provided by the Government is the provision of fiscal incentives. Several alternative fiscal incentives can be given to coal gasification industry developers, including tax holidays, tax allowances, and exemption from import duties for raw materials and machinery and equipment. In addition, it is also possible to provide integrated Special Economic Zone facilities and to postpone or reduce royalty payments or special prices for mine-mouth coal downstream. Another support is the certainty of the final product price of the gasification industry. However, another important key is the seriousness and political will of the Government to make the coal gasification industry program a success.

\section{Research Method}

The research method used is a mixed method that combines qualitative and quantitative approaches. The quantitative method in this study uses BCA to create a benefit and cost scenario that provides financial incentives for the Indonesian coal-gasification industry. The formula is as follows: (Salman, 2017; Zulfiandri, 2017).

Where,

$$
P V^{i}=\left(B_{0}^{i}-C_{0}^{i}\right)+\frac{\left(B_{1}^{i}-C_{1}^{i}\right)}{(1+r)}+\ldots+\frac{\left(B_{T}^{i}-C_{T}^{i}\right)}{(1+r)^{T}}
$$

$P V^{i}=$ Present Value project $\mathrm{i}$

$\mathrm{B}_{\mathrm{t}}^{\mathrm{i}}=$ Benefit from project $\mathrm{i}$ at time $\mathrm{t}$

$\mathrm{C}_{t=}^{i}$ Cost from project $\mathrm{i}$ at time $\mathrm{t}$

To deepen the study in this study, a qualitative exploratory method was used. In the exploratory qualitative approach, the purpose is to discuss and analyze by digging deeper into various information regarding the policy of providing financial incentives for investment in the coal gasification industry in Indonesia. Well, springs of information and data in a subjective methodology in this investigation are to look for data from strategy producers about financial impetuses to help the coal-gasification program in Indonesia, just as through Focus Group Discussions (FGD) and writing considers. The fiscal incentive policy scenarios provided by the Government are tax allowances, charge exclusions and sovereignties which can influence macroeconomic exercises. The information utilized is information from the Central Bureau of Statistics and information from PT. Bukit Asam.

\section{Literature Review}

In the development of the pioneer industry as well as the coal-gasification industry, it will face various obstacles. One of these obstacles is the amount of investment. According to Zhou et al. (2015), there are 5 obstacle factors, one of which is financial factors which are obstacles to business organizations for business development. Other factors are knowledge, technology, economy and social and political factors. One of the financial supports from the government to develop the coal-gasification industry is to provide fiscal 
incentives. The implementation of the current coal-gasification investment fiscal incentives in Indonesia has not yet been implemented, so a study is needed that can be used as a reference or consideration for making decisions on incentives that are given, especially the fiscal incentives for coal-gasification investment. Price (2014), in his writings, mentions the term fiscal incentive as a financial incentive. He also mentioned that financial incentives coming from the government were considered very important to improve the development and operation of the company. To be effective, these fiscal incentives must cover the costs and risks between projects and the industries in which they operate. In addition, pioneer project developers must consider financial incentives from the government as one of the predictions that will be made during the planning, construction and operation period of a project. Fiscal incentive policies are also defined as government policies carried out to utilize state expenditures and revenues to influence economic conditions. Some examples of fiscal incentive policies are royalties, tax holidays, import duty incentives, export duties, tax incentives, and subsidies.

The government's fiscal incentives in recent years are aimed at anticipating the impact of the global economic crisis and various other economic conditions. This fiscal incentive is also expected to be a catalyst, namely the maintained level of consumption and investment that will be able to encourage economic growth (ekonomi.bisnis.com, 2020). Several studies have noted that fiscal incentives can have both negative and positive impacts on investment in several countries. A study conducted by Fowowe (2013) in Nigeria, turns out that fiscal incentives have a negative impact on investment. Meanwhile, the results of the study of Mousley et al. (2009) stated that fiscal incentives in the form of tax holidays became ineffective because at the same time the tax holiday was given, it turned out that investors had spent a lot of relatively large capital. On the other hand, another study says that fiscal incentives have a positive impact on investment in a country. Like the study that was conducted by Cleeve and Botman (2008). According to them, the impact of fiscal incentives actually encourages foreign investment (the case of 16 African countries for the period 19902000). In addition, the tax holiday is one of the important things to encourage more foreign investment. To support the analysis of the benefits and disadvantages of fiscal incentives in various countries, Benefit-Cost Analysis (BCA) is used. According to Nuryadi (2014), BCA is an economic analysis used to calculate two variables, namely the benefit variable and the cost variable. This method is widely used to evaluate the use of economic resources with the aim that these economic resources are used efficiently.

\section{Results and Discussion}

According to the 2019 World Statistics Agency report on energy, Indonesia's coal reserves account for more than $3 \%$ of the world's coal deposits. Meanwhile, coal reserves owned by several countries, including the United States 26\%, Russia 18\%, China 13\%, Australia 9\%, India 7\%, Germany 5\%, Ukraine 4\%, Poland 4\%, South Africa 9\%, and the remaining $9 \%$ spread in various other countries. Indonesia's large coal reserves need to be optimized for use. Currently, the Government of Indonesia remains consistent in the success of the coal downstream policy, remembering expanding the additional worth of coal for the type of coal gasification. This policy is expected to increase national economic growth. Apart from being carried out through fiscal disincentive policies in the form of imposition of export duty rates, also through the provision of fiscal incentives. This fiscal incentive is predicted to boost investment in the downstream mining commodity industry.

Meanwhile, the imposition of export duties is in principle based on the state levies policy, does not interfere with economic growth. Increases poverty alleviation and provides employment and income distribution. In addition, the coal-gasification industry policy also continues to pay attention to the impact of weakening exports of this commodity on society. The government can provide an alternative source of new livelihoods or other types of work that can reduce the adverse effects of layoffs or weakening economic activity. The government can also consider providing affirmative policies (policies that favor certain groups), such as assistance for basic necessities and basic services for communities and workers, especially around mining areas (Abidin, 2014). Basically, the execution of disincentive strategies and other monetary motivating forces for mineral and coal is planned as a momentary arrangement on restricting mineral and coal sends out which adversely affects the Indonesian economy, specifically causing a decrease in crude mineral fares and new interest in the mining area. 
In any case, approaches with respect to sending out limitations will emphatically affect the economy if it is upheld by the advancement of new interest in the mineral and coal area. This is with the goal that Indonesia can send out handled mineral and coal wares (Amir, 2013). This policy is also intended to encourage the downstream activities of the coal mining sector, especially the production of coal gasification and other derivative products which are expected to have higher added value. Adjustment of disincentive policies and other fiscal incentives is also one of the incentives that will be able to encourage and accelerate the construction of smelters and coal-gasification production technology and other supporting production. The results of coal mining activities have several qualities such as high-calorie quality, medium calorie and low calorie. In general, high calorie and medium calorie coal products for mining entrepreneurs tend to be directly sold or exported with the hope that the price is relatively high.

In fact, low-calorie coal will be sold domestically at a relatively low price. The government sets the lowest price especially for the supply of Steam Fired Power Plant to State Electricity Enterprise, which is USD 70 per metric ton. Therefore, the Government has carried out different approaches to expand the additional worth of coal mining items as a downstream program. There are several steps a coal mining company can take. First, direct use of coal, which is usually used by power generation companies, the textile industry, the cement industry, the fertilizer industry and others. Second, conversion, through further processing, this method is through subsequent processing such as gasification, liquefaction, cokes, activated carbon and coal slurry. Third, increasing the value of coal (upgrading), increasing this value, among others, through coal cleaning technology. This can be described as follows:

\section{Figure 1: Derivatives of Coal Down Streams Activities}

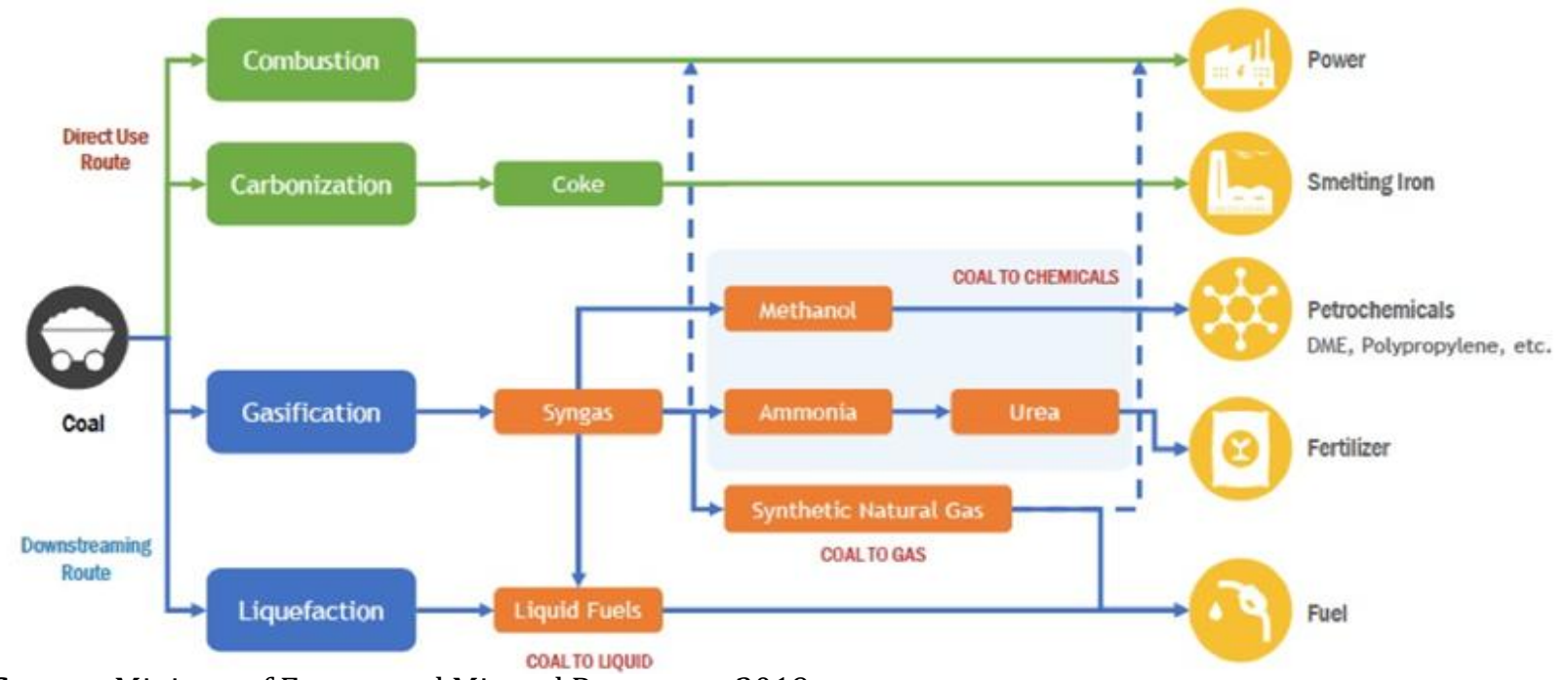

Source: Ministry of Energy and Mineral Resources, 2019

Currently, the coal downstream program that will be developed includes coal gasification. One of the stateclaimed companies that have the chance to attempt a gasification project is PT. Bukit Asam. This company will form coal into a gas (syngas) which is then changed over into methanol and afterward transformed into Dimethyl Ether (DME) and Polypropylene (PP). Two regions will create, specifically in Tanjung Enim, South Sumatra and part of the Riau district. These two regions are required to have the option to produce DME of 400 Kilo Ton Annually (KTA) and 1,400 KTA (BPS, 2016). Theccoalsgasificationsprocess is the activity of converting coal into gas products (especially $\mathrm{CO}$ and $\mathrm{H} 2$ ). This project requires a large investment at the beginning of its establishment and it is hoped that the raw material used in the gasification industry process is low-quality coal which can be added value. The benefits of developing the coal-gasification industry include the absorption of raw materials in the form of low-quality coal. It is also hoped that the coal-gasification industry will later be able to supply national gas needs so that it can reduce gas imports, which means saving foreign exchange. On the other hand, some products can be produced by the coal-gasification industry, such as ammonia as the main material for fertilizer production and material for the production of plastic ore. 
In addition, the positive impacts arising from the coal-gasification industry include growing the national and regional economies, absorbing labor, increasing state revenue from tax and non-tax sides as well as growing similar industries in other regions. The government continues to encourage the downstream process of coal, such as the coal-gasification process. This is expected to be a step to meet national energy needs. However, the challenges and obstacles to the coal-gasification process are still great, such as the need for complex technology, relatively large investment and limited infrastructures such as limited electricity supply and transportation. Another problem is the overlapping authority with other sectors and the absence of regulations governing permits and trading systems for the exploitation of coal processed products. Likewise, institutionally, organizations that handle coal still have overlapping duties and functions. For example, the Ministry of Energy and Mineral Resources deals with the three first echelons of coal, such as the General Administration of Mines and Coal, the General Administration of Renewable Energy and Energy Conservation, and the General Administration of Petroleum and Natural Gas.

On the other hand, the Ministry of Industry and Information Technology also deals with coal. Another problem is the determination of the application of royalties (whether in terms of coal or coal-derived products). Not to mention environmental problems as a result of coal mining and pollution due to burning using coal. However, currently, the coal-gasification industry has been developed by several countries, apart from the United States it is also developed in China, Japan, South Korea, Australia and Mongolia. By benchmarking several examples of countries that have carried out the gasification industry, it is hoped that in the future the coal-gasification industry can be developed in Indonesia. The government's task is to encourage through various policies, such as fiscal incentives so that investment in the coal-gasification industry can grow and develop rapidly. This is in line with government policies to achieve national energy security. Data (BPPT, 2018) shows that the national energy demand for LPG, gas, electricity and others until 2050 continues to increase. As the following data.

Figure 2: National Energy Demand Roadmap (2016-2050)

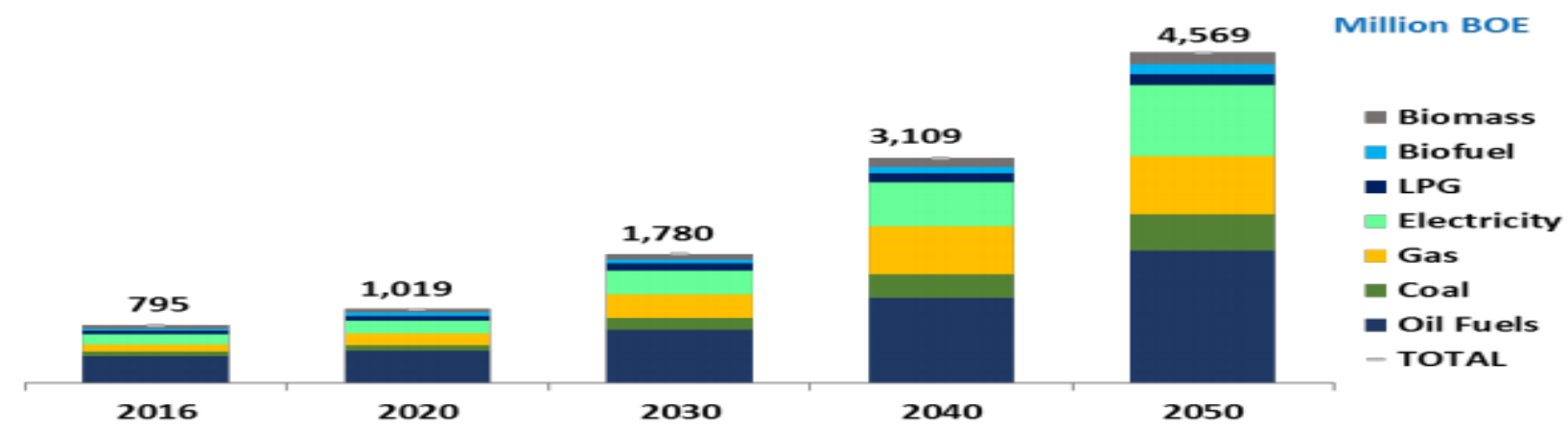

Source: BPPT, 2018 (BOE = barrel of oil equivalent)

It is estimated that the demand for gas, LPG will continue to rise. The increase in gas demand until 2050 is estimated to be more than 7.9 times or an average increase of 6.3 percent. At the same time, demand for coal continues to increase in line with an average growth of 6.3 percent per year. One of the reasons is the relatively rapid development of the coal-based industry. In addition, the use of coal, which is a fuel for power plants, continues to increase.

Impact of Indonesia's Coal-Gasification Industry: Indonesia's coal-gasification industry plan has had an impact on improving the national economy in multiple sectors, including the economy, industry, taxation, and investment sectors. For example, in the case study of PT. Bukit Asam, as one of the mining companies in Indonesia's downstream coal pilot project. The company is expected to operate as a coal gasification industry company in 2022. The impact of increased coal production and downstream investment on the national GDP was US\$7,392,523,710, compared with US\$4,568,966,610 in 2017. The impact of PT Bukit Asam's increase in coal production on GRDP in 2022 is estimated to be USD 170,917,500 and USD 2,911,333,148 of investment. The value of PT Bukit Asam's coal-gasification proceeds is estimated to be US $\$ 1,163,363,030$, and the resulting externality is estimated to be US $\$ 292,564,190$. The total value of social benefits obtained by the PT 
Bukit Asam coal-gasification industry is estimated to be US\$478,592,253. In this study, the benefit coefficient of downstream coal-gasification at PT Bukit Asam was 0.41 .

For taxes revenue when coal gasification is downstream by PT Bukit Asam, it is assessed that USD $564,954,468$ will be gotten, comprising of taxes revenue externalities assessed at USD 380,355,100, an excess payment is assessed at USD 64,019,216 and an economics rents factor of USD 380,355,100. USD 120,580,152. Possible Non-Tax State Revenue starting from creation charges (royalties), fixed expenses (deadrents), woodland duties, and profits subsequent to downstreaming is assessed at USD 69,055,821, which comprises of non-charge state incomes for the middle USD 17,366,003, the Regional Government of South Sumatra Province USD 14,233,593 and the Regional Government of Muara Enim USD 37,010,659. It is assessed that a few kinds of charges will increment with the downstream of coal gasification. A portion of the duties that will increment incorporate Land and Building Tax and Surface Water Tax. Then again, the coal downstream program as gasification has resulted in expanding financial development in regions where the coal gasification industry is established. Coming up next is an outline of the effect of downstream and speculation on the GRDP of Muara Enim Regency. It tends to be seen that in 2017 (preceding there were downstream exercises) coal GRDP of Muara Enim Regency was USD 3,212,544,000. After the foundation of the coal gasification industry in 2022, it is assessed that the GDP of the worth of coal creation will be USD $7,792,629,600$. This implies that there is an expansion in the GDP of coal gasification production by more than 2.50 times. As delineation, with the downstream of coal there will be an expansion in the speed of the economy, an increment underway worth and an increment in venture and business. A valid example of coal downstream at PT Bukit Asam which is situated in Muara Enim Regency.

With this downstream, it is assessed that the PDRB of Muara Enim Regency will increment, retaining in excess of 5,000 laborers. This increment in the number of laborers came from a few areas. The most predominant area, among others, is the coal area, which is required to ingest a labor force of 2,403 individuals. At that point followed by the compound and plastic industry area (306 individuals), the discount and retail exchange area (398 individuals), the corporate administrations' area and building renting (459 individuals), the street transport area (223 individuals) and a few different areas. The coal downstream completed by PT Bukit Asam is likewise expected to build charge income because of the creative interaction of coal into a few different items like items for urea (ammonia) compost as crude material, DME as crude material for gas and polypropylene (PP) as a plastic material. From the reenactment of Business Entity Tax and Individual Tax income, the downstream Polypropylene is focused to add to Corporate Income Tax of USD 1,061,976. Then, downstream DME expanded Corporate Income Tax by USD 357,776 and for Urea expanded Corporate Income Tax by USD 253,673. In like manner, a singular personal assessment will likewise increment. The public authority is steady of establishments or business elements that will complete coal-gasification downstream by giving different offices and fiscal incentives. Fiscal's incentive force backing can be given to organizations that will do the coal-gasification industry by continually thinking about the positive effect on the public and territorial economies and expanding expectations for everyday comforts and advantages for the social government assistance of the local area.

As delineation, coming up next is an examination of the cost and benefit got through giving, incentives. For instance, if the Government diminishes the royalty rate from 13.5 percent or USD 14,290,744 to 0 percent for a business substance that completes gasification downstream, like PT Bukit Asam, it implies that state income for the middle is decreased by USD 2,857,602. Provincial incomes (South Sumatra territory and Muara Enim locale) add up to USD 11,433,460. On the off chance that motivators are accommodated the coal-gasification industry, it will expand benefits for the local and central governments. The central government will actually want to save foreign exchange reserves of USD 848,120,320 because Indonesia can deliver PP and DME and get extras foreign exchange of USD 147,737,088 on the grounds that it can send out manures from ammonia from coal downstream. Similarly, for the regional government, Muara Enim Regency's PDRB has increased in the form of additional coal production, estimated at US\$201,663,180 and an additional investment of US $\$ 2,704,337,424$. Another impact is the absorption of labor, which is estimated to be 5,578 people. The social welfare value of the Muara Enim Regency is US\$474,674,340. From various perspectives, there are several aspects of the benefits obtained, so the government can provide financial incentives to pioneer companies such as PT Bukit Asam. Some of these aspects include increasing the national economy and local government, such as increasing national income, social welfare, and increasing employment, as well as the 
positive impact on the downstream areas of the coal-gasification industry. However, on the other hand, there is a need for clear regulatory arrangements regarding fiscal incentives for the coal-gasification industry because it has the potential for irregularities.

\section{Conclusion and Recommendations}

If the fiscal incentive policy scheme is applied to the coal-gasification industry, such as reducing royalty rates and other taxes, in the short term it will reduce state revenues from the tax revenue sector. However, in the long term, the benefits of this policy scheme will have an impact on improving the national economy as well as the regional economy. It is estimated that there will be a 2.5 -fold increase in GDP and GRDP. Likewise, tax and non-tax revenues also increased 2.5 times on average. On the other hand, it will provide social benefits as well as employment which is estimated to be more than 5000 workers. To support the coal-gasification industry, which will be carried out by PT Bukit Asam as a pioneer company, the Government can provide fiscal incentives in the form of reducing royalty rates and other taxes. The success of this pioneer company is expected to have an impact on other companies to carry out the same development in the coal-gasification industry sector in Indonesia.

\section{References}

Anjar, W. A., Hayadi, B. H., Subekti, P., Sudrajat, D., Wikansari, R., Bhawika, G. W. \& Surya, S. (2019, August). Forecasting the Export and Import Volume of Crude Oil, Oil Products and Gas Using ANN. In Journal of Physics: Conference Series, 1255(1), 012016.

Alin, H., Budy P. \& Resosudarmo. (2004). Tingkat Ekstraksi Optimal Minyak Bumi Indonesia: Aplikasi Model Optimasi Dinamik. Jurnal Ekonomi dan Pembangunan Indonesia, 01,11-34.

Antara, M. (2009). Dampak Pengeluaran Pemerintah dan Wisatawan Serta Investasi Swasta Terhadap Kinerja Perekonomian Bali: Suatu Simulasi Model Accounting Matrix, 1-23.

Amir, H. (2013). Economic Impact Analysis of the Indonesia Mineral-Export Tax Policy: A CGE Approach. The International Journal of Economic Policy Studies, 8, 1-22.

Abidin, M. \& Zainul. (2014). Rasionalitas dan Evaluasi Penetapan Bea Keluar Dalam Rangka Mendukung Kebijakan Pengelolaan Mineral. Jurnal Bina Praja, 6(2), 129-142.

Badan, G. (2018). Potensi Mineral dan Batubara Indonesia. Bandung, 1-9.

Boadway, R. \& Frank, F. (1993). The Taxation of Natural Resources. Principles and Policy Issues. The World Bank, 1-72.

BP Statistical Review of World Energy. (2016). Outlook 2016. London, 36.

BPS (Indonesian National Statistical Office). (2016). Documentation for the Indonesian Social Accounting Matrix (SAM), 1-720.

Deon, A. \& Julius, C. A. (2019). Indonesia's Coals Dynamics: Toward a Just Energy Transition. Institute for Essential Services Reform (IESR) Jakarta. Indonesia First Edition, 1-48.

Directorate General of Budget, Ministry of Finance of Indonesia. (2020). List of Natural Resources Revenue, Mineral and Coal, 1-327.

Cleeve, E. (2008). How Effective Are Fiscal Incentives to Attract FDI to Sub-Saharan Africa? Journal of Developing Areas, 42(1), 135-153.

Ekonomi.bisnis.com. (2020). Kamus Ekonomi: Apa itu Insentif Fiskal. Downloaded July 25, 2020 from https://ekonomi.bisnis.com/read/20130823/9/158344/kamus-ekonomi-apa-arti-insentif-fiskal

Fei, M. (2016). Underground Coal Gasification (UCG): A New Trend of Supply-Side Economics of Fossil Fuels. Natural Gas Industry B, 3(4), 312-322.

Fowowe, B. (2013). Do Fiscal Incentives Promote Investment? Empirical Evidence from Nigeria. The Journal of Developing Areas, 47(2), 17-35.

Indonesian Ministry of Energy and Mineral Resources, Directorate General of Mineral and Coal. (2019). Mineral and Coal Downstream Program, 1-40.

Kontan. (2020). PT BA Pastikan Investasi Gasifikasi Batubara Ditanggung Mitra. Di akses tanggal 29 April 2021, dari https://industri.kontan.co.id/news/bukit-asam-ptba-pastikan-investasi-proyekgasifikasi-batubara-ditanggung-mitra.

Lembaga Penyelidikan Ekonomi dan Masyarakat Fakultas Ekonomi Universitas Indonesia (LPEM). (2006). Kebijakan Pungutan Ekspor batu Bara, Laporan Akhir, LPEM FE UI, 1-68. 
Marques, C. \& Antonio. (2019). Is there a resource curse phenomenon for natural gas? Evidence from countries with abundant natural gas. Resources Policy, (63), 1-1.

Media Industri Kemenperin. (2016). Wujudkan Hilirisasi Industri Berbasis Sumber Daya Alam, 1-66.

Ministry of Energy and Mineral Resources Republic of Indonesia. (2017). Handbook of Energy \& Economic Statistics of Indonesia, 38.

Mousley, P., Babalola, A. \& Espina C. (2009). Building the Enterprise Sector for Employment and Growth: Some Policy Options, in World Bank: Nigeria Employment and Growth Study. Washington D.C.: World Bank, 1-304.

Nuryadi. (2014). Cost Benefit Analysis Antara Pembelian Alat Ct-Scan dengan Alat Laser Dioda Photocoagulator di Rumah Sakit Daerah Balung Jember. Jurnal Ikesma, 10, 49-58.

Price, P. J. (2014). Effectiveness of Financial Incentives for Carbon Capture and Storage. Ieaghg.org. Bluewave Resources, LLC McLean, Virginia, USA, 1-14.

Pupuk Indonesia. (2018). Kajian Internal Rate of Return tahun, 1-774.

Salman, F. (2017). Cost and Benefit Analysis of RSPO Certification (Case Study in PT BCA Oil Palm Plantation in Papua). Indonesian Journal of Business and Entrepreneurship, 3(3), 219-228.

Suthichaimethee, P. (2018). A Relation of Causal Factors in the Economic, Social, and Environmental Aspects Affecting the Implementation of Sustainability Policy in Thailand: Enriching the path Analysis Based on a GMM Model. Journal Resources, 7(4), 87.

United Nations Hanbooks. (2017). Taxation of the Extractive Industries by Developing Countries, United Nations, New York, 1-491.

Wang, D. (2017). Energy price slump and policy response in the coal-chemical industry district: A case study of Ordos with a system dynamics model. Journal Energy Policy, (104), 325-339.

Zhou, K., Taigang L. \& Lifeng, Z. (2015). Industry 4.0: Towards future industrial opportunities and challenges. In Fuzzy Systems and Knowledge Discovery (FSKD), IEEE 12th International Conference, 2147-2152.

Zulfiandri. (2017). Transaction Cost and Benefit-Cost on Vertical Integration of Cacao Small Scale Agroindustry Value Chain. Journal of Management and Agribusiness, 14, 187-197. 